\title{
Gambaran Kasus Kematian dengan Asfiksia di Bagian Kedokteran Forensik dan Medikolegal RSUP Prof. Dr. R. D Kandou Manado Periode 2013 - 2017
}

\author{
${ }^{1}$ Nikita E. K. Rey \\ ${ }^{2}$ Johannis F. Mallo \\ ${ }^{2}$ Erwin G. Kristanto
}

\author{
${ }^{1}$ Program Studi Pendidikan Dokter Fakultas Kedokteran Universitas Sam Ratulangi Manado \\ ${ }^{2}$ Bagian Ilmu Kedokteran Forensik dan Medikolegal Fakultas Kedokteran \\ Universitas Sam Ratulangi Manado \\ Email: nikitaester05@gmail.com
}

\begin{abstract}
Asphyxia was a condition cause by lack of oxygen and excess of carbon dioxide in the blood. There are three types of asphyxia: mechanical, non-mechanical, and pathologic asphyxia. This study was aimed to obtain the general description of death cases due to asphyxia in Manado North Sulawesi in the period 2013-2017. This was a descriptive retrospective study using the medical record of cases at Forensic and Medicolegal Department of Prof. Dr. R. D. Kandou. The results of visum et repertum showed that there were 26 death cases due to asphyxia. Most cases were in 2016 (10 cases, 38.5\%). The most common cases were in age group of 17-25 years old (7 cases, $27 \%)$. Males (17 cases, 65\%) were more frequent than females. Death due to mechanical asphyxia caused by drowning was the most common cases (11 cases; 42.3\%). The most common sign of asphyxia was cyanosis (21 cases). Conclusion: Majority of the death cases due to asphyxia were males, age group 17-25 years, with mechanical asphyxia caused by drowning and cyanosis as the asphyxia sign.
\end{abstract}

Keywords: asphyxia, mechanical asphyxia, non-mechanical asphyxia, pathology asphyxia, forensic

\begin{abstract}
Abstrak: Asfiksia adalah suatu kondisi yang disebabkan karena berkurangnya oksigen dan berlebihnya karbon dioksida dalam darah. Asfiksia terdiri dari tiga jenis klasifikasi yaitu asfiksia mekanik, non-mekanik, dan patologik. Penelitian ini bertujuan untuk mengetahui gambaran umum tentang kasus kematian dengan asfiksia di Manado Sulawesi Utara periode 2013-2017. Jenis penelitian ialah deskriptif retrospektif menggunakan data hasil visum et repertum. Hasil penelitian mendapatkan 26 kasus kematian dengan asfiksia. Kasus terbanyak pada tahun 2016 yaitu 10 kasus (38,5\%). Kelompok usia terbanyak ialah 17-25 tahun sebanyak 7 kasus (27\%). Jenis kelamin laki-laki lebih banyak dari perempuan yaitu 17 kasus (65\%). Kematian akibat asfiksia mekanik dengan jenis tenggelam merupakan kasus terbanyak yaitu 11 kasus $(42,3 \%)$. Tanda asfiksia yang sering ditemukan ialah sianosis (21 kasus). Simpulan: Sebagian besar kasus kematian akibat asfiksia berjenis kelamin laki-laki, kelompok usia 17-25 tahun, dengan jenis asfiksia mekanik akibat tenggelam, dan sianosis sebagai tanda asfiksia.
\end{abstract}

Kata kunci : asfiksia, asfiksia mekanik, asfiksia non-mekanik, asfiksia patologi, forensik

Asfiksia adalah suatu kondisi yang disebabkan oleh berkurangnya oksigen dan berlebihnya karbon dioksida dalam darah. Hal ini terjadi oleh karena adanya ganggu- an pertukaran antara oksigen dalam alveoli paru-paru dengan karbon dioksida dalam darah kapiler paru-paru. ${ }^{1}$ Secara umum asfiksia disebabkan oleh karena penyum- 
batan saluran pernapasan, trauma dan keracunan bahan kimiawi. ${ }^{2}$

Kasus kematian akibat asfiksia cukup mendapatkan perhatian karena mekanisme kematiannya sangat cepat. Penurunan kesadaran dapat terjadi dalam waktu 40 detik kemudian korban meninggal setelah beberapa menit. ${ }^{3}$

Asfiksia merupakan salah satu penyebab kematian yang sering ditemukan dalam kasus kedokteran forensik di dunia. Menurut data dari Centers for Disease Control (CDC) tahun 1999-2004 di Amerika Serikat didapatkan sekitar 20.000 kasus kematian disengaja maupun tidak disengaja. ${ }^{4}$ Di Pakistan, menunjukkan bahwa jumlah total kematian akibat asfiksia sebanyak 130 kasus kematian dari total 3.265 kasus kematian. Kematian akibat gantung diri merupakan yang paling banyak terjadi. ${ }^{5}$ Studi yang dilakukan di India mendapatkan hasil kematian akibat asfiksia sebanyak 3960 kasus $(21,23 \%)$ dari total kematian 18.648 pada tahun 2009-2011. ${ }^{6}$

Di Indonesia sendiri kematian akibat asfiksia berada pada urutan ke-3 sesudah kecelakaan lalu lintas (KLL) dan trauma mekanik. ${ }^{7}$ Berdasarkan data yang dilaporkan di Bagian Kedokteran Forensik FK UI RSUP Cipto Mangunkusumo tahun 19952004, angka bunuh diri di Jakarta mencapai 5,8\%. Dari 1.119 korban bunuh diri, 41\% di antaranya gantung diri, $23 \%$ bunuh diri dengan minum obat serangga, dan sisanya 356 tewas karena overdosis obat-obatan terlarang. Kasus bunuh diri tersebut disebabkan karena masalah psikologis, sosial, dan ekonomi. ${ }^{8}$

Dari penelitian Robi et al. ${ }^{9}$ kasus kematian asfiksia mekanik di Manado didapatkan sebanyak 22 kasus. Kasus terbanyak terjadi pada tahun 2011 sebanyak 8 kasus (32\%), dan tertinggi ditemukan pada kelompok usia 17-25 tahun dengan 7 kasus $(31.8 \%)$.

\section{METODE PENELITIAN}

Jenis penelitian yang digunakan ialah deskriptif retrospektif. Sampel yang diambil ialah kasus kematian dengan asfiksia di Bagian Kedokteran Forensik dan Medikolegal RSUP Prof. Dr. R. D. Kandou periode 2013-2017. Variabel penelitian yang diteliti yaitu jumlah kasus kematian dengan asfiksia per-tahun, usia, jenis kelamin, jenis asfiksia, dan tanda-tanda asfiksia yang ditemukan pada jenazah.

\section{HASIL PENELITIAN}

Pengumpulan data berdasarkan hasil visum et repertum pada kematian dengan asfiksia di Bagian Kedokteran Forensik dan Medikolegal RSUP Prof. Dr. R. D Kandou selama periode 5 tahun yaitu pada tahun 2013-2017 mendapatkan sebanyak 26 kasus kematian.

Total jumlah kematian dengan asfiksia yang masuk di Bagian Kedokteran Forensik dan Medikolegal RSUP Prof. Dr. R. D Kandou Manado selama periode tahun 2013-2017 sebanyak 26 kasus. Kematian dengan asfiksia terbanyak ditemukan pada tahun 2016 sebanyak 10 kasus dari total 183 kasus kematian yang masuk di Bagian Kedokteran Forensik dan Medikolegal RSUP Prof. Dr. R. D Kandou Manado pada tahun tersebut. Urutan kedua terbanyak ditemukan pada tahun 2017 sebanyak 6 kasus dari total 86 kasus kematian pada tahun yang sama. Tahun 2015 diketahui ada 131 total kematian, namun hanya didapatkan 1 kasus kematian dengan asfiksia. Hal ini menunjukkan bahwa tahun 2015 memiliki jumlah kasus kematian dengan asfiksia yang paling sedikit selama periode 2013-2017 (Tabel 1).

Tabel 1. Jumlah kasus asfiksia per tahun

\begin{tabular}{ccc}
\hline Tahun & Kasus & Persentase (\%) \\
\hline 2013 & 4 & $15,4 \%$ \\
2014 & 5 & $19,2 \%$ \\
2015 & 1 & $3,8 \%$ \\
2016 & 10 & $38,5 \%$ \\
2017 & 6 & $23,1 \%$ \\
Total & 26 & $100 \%$ \\
\hline
\end{tabular}

Kematian dengan asfiksia menurut kelompok usia terbanyak dialami pada kelompok usia 17-25 tahun yaitu sebanyak 
7 kasus (27\%) dari total 26 kasus, diikuti kelompok usia 26-35 dan 46-55 tahun dengan jumlah kasus yang sama yaitu 5 kasus (19,2\%). Tidak didapatkan kasus kematian dengan asfiksia pada kelompok usia > 65 tahun (Tabel 2).

Tabel 2. Distribusi kasus menurut usia

\begin{tabular}{ccc}
\hline $\begin{array}{c}\text { Kategori usia } \\
\text { (tahun) }\end{array}$ & Jumlah & $\begin{array}{c}\text { Persentase } \\
(\%)\end{array}$ \\
\hline $0-5$ & 2 & $7,7 \%$ \\
$6-11$. & 1 & $3,8 \%$ \\
$12-16$. & 2 & $7,7 \%$ \\
$17-25$ & 7 & $27 \%$ \\
$26-35$ & 5 & $19,2 \%$ \\
$36-45$ & 3 & $11,6 \%$ \\
$46-55$ & 5 & $19,2 \%$ \\
$56-65$ & 1 & $3,8 \%$ \\
$>65$ & 0 & 0 \\
Total & 26 & $100 \%$ \\
\hline
\end{tabular}

Kematian dengan asfiksia terbanyak yang masuk di Bagian Forensik dan Medikolegal RSUP Prof. Dr. R. D. Kandou Manado periode 2013-2017 ialah laki-laki sebanyak 17 kasus (65\%) sedangkan perempuan sebanyak 9 kasus $(35 \%)$ (Gambar 1).

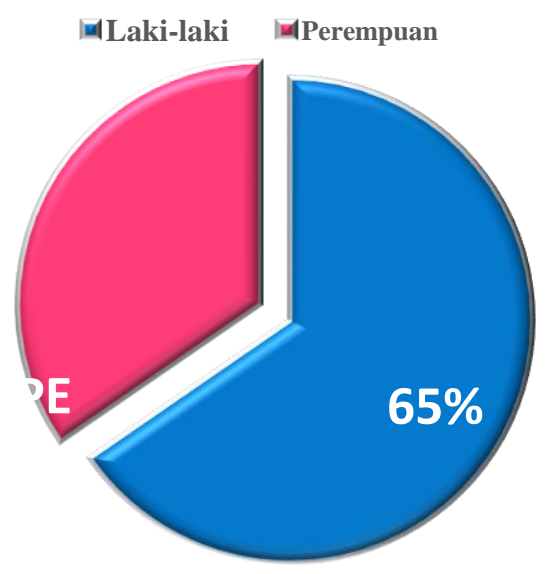

Gambar 1. Diagram jumlah kematian dengan asfiksia berdasarkan jenis kelamin
Jumlah kematian dengan asfiksia yang masuk di Bagian Kedokteran Forensik dan Medikolegal RSUP Prof. Dr. R. D. Kandou Manado selama periode tahun 2013-2017 memperlihatkan jumlah kasus terbanyak ialah kematian dengan asfiksia mekanik yaitu 25 kasus (96,2\%); jenis tenggelam merupakan kasus terbanyak dengan jumlah 11 kasus (42,3\%). Tidak ditemukan kematian dengan asfiksia non-mekanik, sedangkan untuk asfiksia patologik hanya didapatkan 1 (satu) kasus saja $(3,8 \%)$ (Gambar 2).

Tanda yang paling sering ditemukan pada kasus kematian dengan asfiksia yakni sianosis dengan jumlah 21 kasus. Tanda terbanyak kedua yang didapatkan yaitu busa halus pada 9 kasus, diikuti oleh kongesti pada 7 kasus. Pada penelitian ini, tidak ditemukan tanda-tanda asfiksia seperti perdarahan faring, patah tulang lidah, darah yang tetap cair, hingga edema pulmonal (Gambar 3).

\section{BAHASAN}

Dari hasil penelitian dapat dilihat bahwa kematian dengan asfiksia di Bagian Kedokteran Forensik dan Mediko-legal RSUP Prof. Dr. R. D. Kandou Manado selama periode Tahun 2013-2017 tidak cenderung meningkat ataupun menurun setiap tahunnya, melainkan bersifat fluktuatif atau tidak menentu (Tabel 1). Hal ini diduga karena tidak semua korban kematian dengan asfiksia masuk ke RSUP Prof. Dr. R. D. Kandou. Salah satunya bergantung pada dimana korban ditemukan, dan bila polisi menganggap barang bukti di tempat kejadian perkara (TKP) sudah cukup serta hanya memerlukan surat kematian di RSUD setempat, maka jenazah tidak dibawa ke RSUP Prof. Dr. R. D. Kandou. Demikian pula bila polisi menganggap bukti yang ditemukan sudah cukup, dan keluarga korban menerima, maka pemeriksaan jenazah tidak perlu dilakukan. 


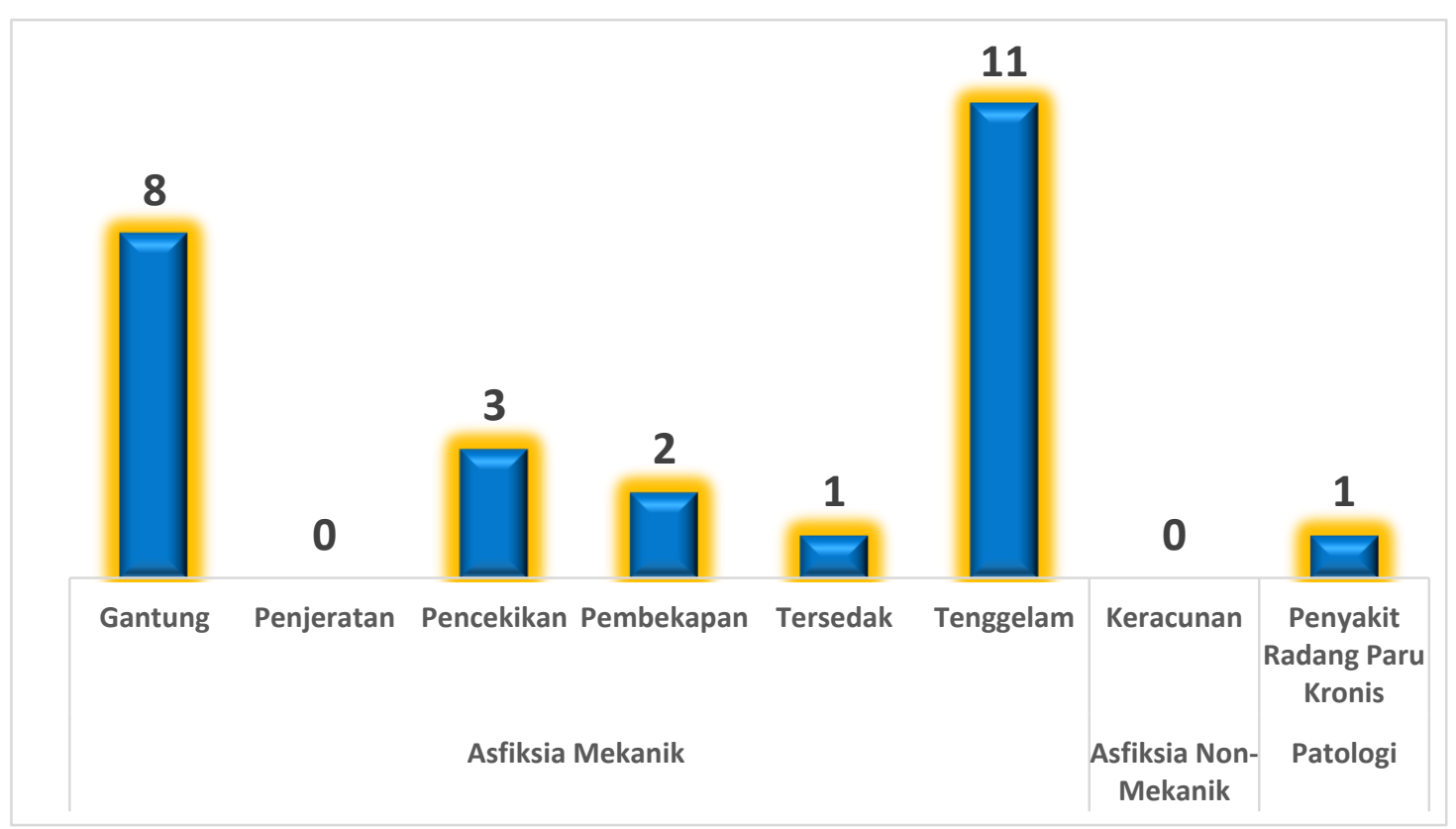

Gambar 2. Grafik jumlah kematian dengan asfiksia berdasarkan jenis asfiksia

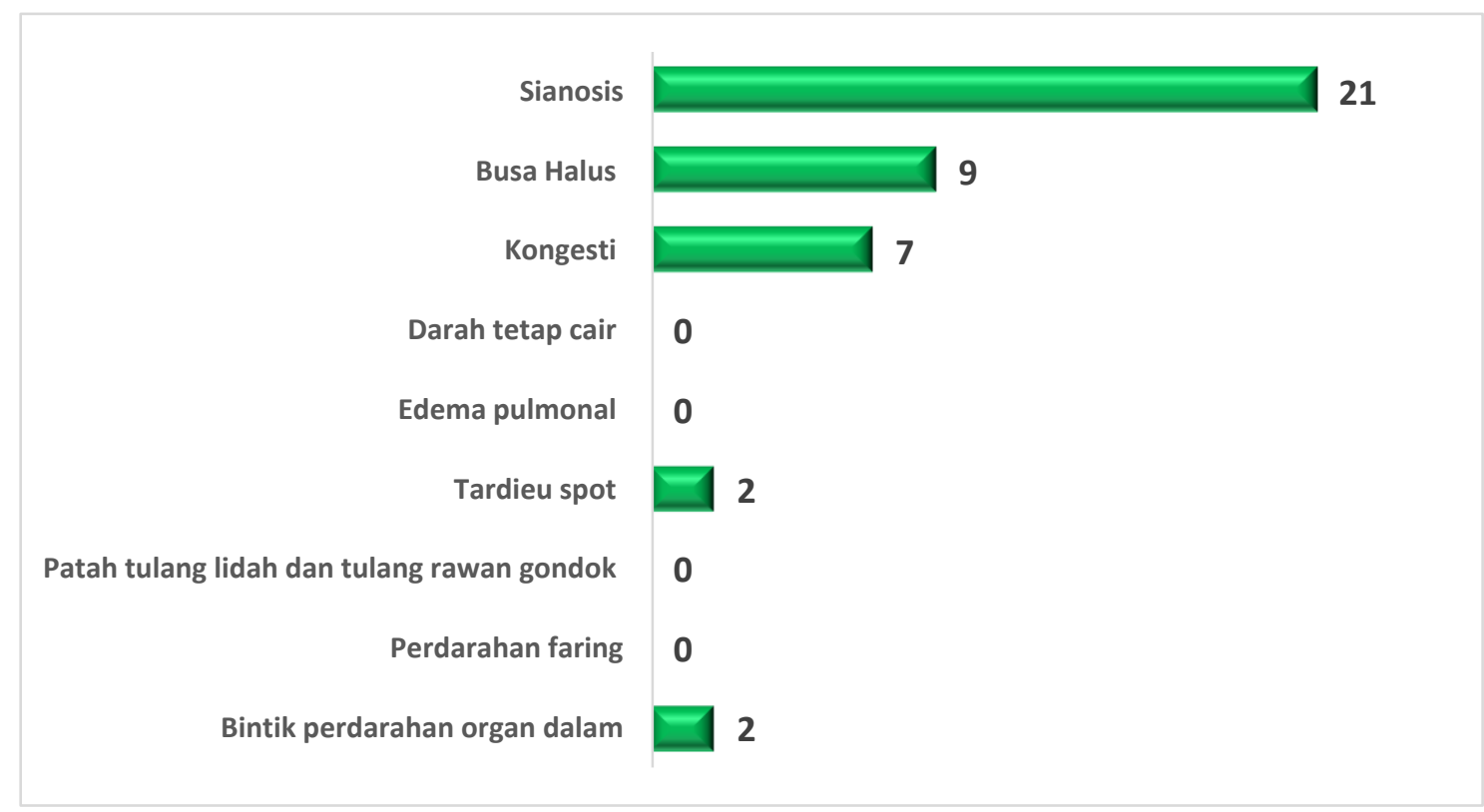

Gambar 3. Grafik jumlah kematian dengan asfiksia berdasarkan tanda-tanda asfiksia yang ditemukan pada jenazah

Jika dilihat dari kelompok usia, kematian dengan asfiksia terbanyak dialami pada kelompok usia 17-25 tahun yaitu sebanyak 7 kasus (33.3\%). Hal ini sejalan dengan penelitian yang dilakukan oleh Khalil et al. ${ }^{5}$ di Peshawar, Pakistan periode tahun 2009-2012, yang mendapatkan angka kematian terbanyak pada kelompok usia remaja akhir sampai dewasa muda sebesar $64.5 \%$.
Hasil penelitian ini menunjukkan bahwa kematian dengan asfiksia terbanyak ialah laki-laki sebanyak 17 kasus $(65 \%)$ sedangkan perempuan sebanyak 9 kasus (35\%). Hal ini sejalan dengan penelitian Khalil et al. ${ }^{5}$ yang melaporkan bahwa kematian dengan asfiksia jauh lebih banyak pada laki-laki dengan jumlah 2.839 kasus dibandingkan perempuan dengan jumlah 426 kasus dari total 3.265 kasus. 
Kematian dengan asfiksia mekanik memiliki persentase hampir $100 \%$ data yakni $96.2 \%$ dengan jenis tenggelam merupakan kasus terbanyak sejumlah 11 kasus $(42,3 \%)$. Pada penelitian yang dilakukan oleh Wulur et al. ${ }^{10}$ di Manado periode Januari 2007-Desember 2011 mengenai kasus tenggelam, kematian akibat tenggelam didapatkan pada laki-laki (12 kasus; 80\%) lebih banyak dari pada perempuan. Penelitian ini tidak sejalan dengan penelitian yang dilakukan di Bangladesh, karena jenis kematian dengan asfiksia yang paling banyak ditemukan di Bangladesh ialah jenis kematian dengan gantung (88,5\% dari kematian). Badan Kesehatan Dunia (WHO) mencatat pada tahun 2000 di seluruh dunia terdapat 400.000 kejadian tenggelam yang artinya angka ini menempati urutan kedua setelah kecelakaan lalu lintas. ${ }^{11}$ Sulawesi Utara merupakan daerah yang sering dikunjungi oleh wisatawan karena Sulawesi Utara merupakan daerah tujuan wisata unggulan khususnya bagi para penyelam, sehingga tenggelam menjadi kematian dengan asfiksia terbanyak. Hal ini juga disebabkan karena jenazah warga negara asing (WNA) harus dibawa ke RSUP Prof. Dr. R. D. Kandou Manado untuk dilakukan pemeriksaan, mengingat hal ini berhubungan dengan laporan kematian yang diperlukan agar jenazah dapat dipulangkan ke negaranya, serta sebagai syarat yang digunakan bagi keluarga korban untuk mendapatkan jaminan asuransi dan administrasi pada instansi terkait. ${ }^{12}$ Menurut data yang masuk di Bagian Ilmu Kedokteran Forensik dan Medikolegal RSUP Prof. Dr. R. D Kandou Manado periode 2013-2017, pada kasus kematian akibat tenggelam dilakukan pemeriksaan mikroskopik yaitu pemeriksaan getah paru untuk menegakkan diagnosis kematian akibat tenggelam dan untuk mengetahui benda asing seperti pasir dan lumpur yang sering ditemukan pada kasus tersebut.

Kematian akibat gantung juga memiliki jumlah kasus kedua terbanyak dalam penelitian ini, yaitu sebanyak 8 kasus $(30,8 \%)$. Tanda asfiksia yang paling khas ditemukan pada jenazah yaitu adanya luka lecet tekan melingkar berbentuk seperti huruf $\mathrm{V}$ pada leher, hal ini disebabkan oleh trauma benda tumpul pada kulit yang lebarnya dapat sesuai dengan alat penjerat yang digunakan. Pada semua kasus gantung sering ditemukan luka lecet tekan yang berwarna merah kehitaman serta perabaan seperti kertas perkamen. Kematian dengan asfiksia mekanik yang disebabkan karena pencekikan, pembekapan, dan tersedak mempunyai angka kejadian yang sedikit. Kematian dengan asfiksia non-mekanik tidak ditemukan dalam penelitan ini, sedangkan untuk asfiksia patologik didapatkan 1(satu) kasus yang disebabkan oleh penyakit radang paru kronis.

Tanda-tanda yang paling sering ditemukan pada jenazah dalam penelitian ini ialah sianosis (21 kasus), sedangkan tanda yang kedua yaitu busa halus (9 kasus), diikuti dengan kongesti (7 kasus). Hal ini sangat sesuai dengan trias asfiksia yang terdiri dari sianosis, busa halus, serta pembendungan yang sistemik atau kongesti. Namun hal ini tidak sejalan dengan penelitian yang dilakukan oleh Fakultas Kedokteran Mumbai periode 1 Januari sampai 31 Desember 2012, dimana dari hasil pemeriksaan luar dan pemeriksaan autopsi tanda yang paling sering ditemukan yaitu bintik perdarahan sebanyak 48 kasus, diikuti dengan tanda sianosis sebanyak 17 kasus dari total 60 kasus. $^{13}$

Berdasarkan seluruh kematian yang masuk di Bagian Ilmu Kedokteran Forensik dan Medikolegal RSUP Prof Dr. R. D Kandou Manado periode 2013-2017, maka kematian dengan asfiksia masuk dalam 10 besar mekanisme kematian. Dengan demikian asfiksia sangat penting untuk dipelajari dan harus dipahami oleh mahasiswa Fakultas Kedokteran dalam hal memenuhi Standar Kompetensi Dokter Indonesia (SKDI) yaitu kompetensi 3A.

\section{SIMPULAN}

Berdasarkan hasil penelitian dapat disimpulkan bahwa angka kejadian kemati- 
an dengan asfiksia tidak cenderung meningkat ataupun menurun tiap tahunnya, melainkan bersifat fluktuatif atau tidak menentu. Kematian akibat asfiksia paling banyak terjadi pada kelompok usia 17-25 tahun, jenis kelamin laki-laki, asfiksia mekanik dengan jenis tenggelam. serta sianosis sebagai tanda asfiksia.

\section{DAFTAR PUSTAKA}

1. Idries AM. Pedoman Ilmu Kedokteran Forensik (1st ed). Jakarta: Binarupa Aksara, 1997.

2. Payne-James J, Jones R, Karch SB, Manlove J. Asphyxia. In: Simpson's Forensic Medicine (13th ed). London: Hodder \& Stoughton, 2011; p. 151.

3. Arun M. Methods of suicide: A medicolegal perspective. JIAFM. 2006;28 (1):22-6.

4. Michael AG. Pathologhy of Asphyxial Death. 2016. [cited 2017 Aug 13]. Available from:

https://emedicine.medscape.com/article /1988699-overview\#a18.

5. Khalil ZH, Naeem M, Adil M, Khan MZI, Abbas SH, Alam N. Asphyxial death: a four year retrospective study in Peshawar. J Postgrad Med Inst. 2014; 28(1):24-6.

6. Maddileti GB, Mohanty SK, Kumar V, Reddy KB, Bhuvan V, Yamini K. An epidemiological study of suffocation deaths in twin cities of South India. J Indian Acad Forensic Med.
2015;37(3):233

7. Tasmono H. Distribusi kasus kematian akibat asfiksia di Malang Raya yang diperiksa di Instalasi Kedokteran Forensik RSSA Tahun 2006-2007. Malang: Fakultas Kedokteran Universitas Brawijaya; 2007.

8. Fatih MA. Asfiksia dalam Forensik Klinik. 2007. [cited 2017 Aug 14]. Available from:

http://www.klinikindonesia.com/forensi k.php.

9. Robi M, Siwu J, Kristanto E. Gambaran kasus asfiksia mekanik di bagian forensik RSUP Prof. Dr. R. D. Kandou Periode Tahun 2010-2015 [Skripsi]. Manado: Universitas Sam Ratulangi; 2016

10. Wulur RA, Mallo JF, Tomuka DC. Gambaran temuan autopsi kasus tenggelam di BLU RSU Prof. Dr. R. D Kandou Manado Periode Januari 2007Desember 2011 [Skripsi]. Manado: Universitas Sam Ratulangi; 2013.

11. Chang L. Drowning death 2005. [cited 2017 Oct 17]. Available from: http:// wwwmedicinenet,com.

12. Dolinak D, Evan WM, Emma OL. Forensic Pathology: Principles and Practice. London: Elsevier, 2005.

13. Waghmare PB, Chiklhalkar BG, Nanandkar SD. Analysis of asphycial deaths due to hanging. J Indian Acad Forensic Medical. 2014;36 (4):343-5. 